\title{
Pola makan suku asli Papua dan non-Papua sebagai faktor risiko kejadian hipertensi
}

\author{
Food pattern on indigenous Papuans and non-Papuans as a risk factor of hypertension
}

Sarni Rante Allo Bela ${ }^{1}$, Bambang Djarwoto ${ }^{2}$, I Made Alit Gunawan ${ }^{3}$

\begin{abstract}
Background: Hypertension is one of the problems in the medical and public health sector. The prevalence of hypertension in Jayapura City is 23,8\%. Hypertensive disease was ranked $6^{\text {th }}$ among the top 10 diseases in Abepura Hospital. The risk factors, diet containing high fat, high sodium, low potassium and excessive alcohol consumption has contributed to the increasing of blood pressure. Objective: To determine the degree of hypertension difference between Papuans and non-Papuans, and the effect of asupan of fat, sodium, potassium and alcohol consumption as risk factors for hypertension in each tribes. Method: The study was an observational analytic with a case control design. Samples are 248 which is divided in 62 cases and 62 controls on each tribe. Data analysis using statistical independent t-test, Chi-Square, Maentel Haenzel, Multiple Regression Logistic. Results: NonPapuan tribes had 1.9 times higher risk of hypertension stage 2. Fat intake of indigenous Papuans $(O R=3.250)$ and non-Papuans $(O R=3.275)$ correlated significantly. Sodium intake significantly associated in indigenous Papuans, but the non-Papuans, have a significant relation $(O R=2.531)$. There was a correlation between potassium intake in indigenous Papuans $(O R=2.348)$, but the non-Papuans, was not. Consumption of alcohol in indigenous Papuans was significantly associated (OR=2.343), but the nonPapuans, was not. Multivariate analysis showed that psychosocial stress, consumption of alcohol, family history of hypertension, and potassium intake were contributing in indigenous Papuans. Intake of fat, sodium asupan, and obesitas were contribute in non-Papuan tribes. Conclusion: Non-Papuan tribes prone to has hypertension stage 2. In Papuans, fat intake (>30\%), potassium intake $(<2000 \mathrm{mg})$ and excessive alcohol $(\geq 2$ glasses/day) are risk factors. In the non-Papuan, fat intake (>30\%) and sodium intake $(\geq 2300 \mathrm{mg})$ are risk factors for hypertension.
\end{abstract}

KEY WORDS: hypertension, fat intake, sodium intake, potassium intake, alcohol consumption, indigenous Papuan and nonPapuans

\begin{abstract}
ABSTRAK
Latar belakang: Hipertensi merupakan salah satu masalah dalam dunia medis dan kesehatan masyarakat. Prevalensi hipertensi di Kota Jayapura sebesar 23,8\%. Penyakit hipertensi berada pada urutan ke- 6 di antara 10 besar penyakit di RSUD Abepura Kota Jayapura. Faktor risiko pola makan yang mengandung tinggi lemak, tinggi natrium, rendah kalium serta konsumsi alkohol yang berlebih memiliki kontribusi terhadap peningkatan tekanan darah. Tujuan: Mengetahui perbedaan derajat hipertensi antara suku asli Papua dan non-Papua, serta melihat pengaruh asupan lemak, natrium, kalium, dan konsumsi alkohol sebagai faktor risiko hipertensi pada masing-masing suku. Metode: Penelitian observasional analitik dengan rancangan kasus kontrol. Total subjek 248 orang yang terbagi dalam 62 kasus dan 62 kontrol pada masing-masing suku. Pengumpulan data pola konsumsi lemak, natrium (Na), kalium (K) menggunakan FFQ dan konsumsi alkohol serta faktor risiko lainnya menggunakan kuesioner. Analisis data dengan uji statistik independent t-test, Chi-Square, Maentel Haenszel serta regresi logistik ganda. Hasil: Suku non-Papua lebih berisiko 1,9 kali terkena hipertensi stage 2 dibanding suku asli Papua. Asupan lemak suku asli Papua $(\mathrm{OR}=3,250)$ dan non-Papua $(\mathrm{OR}=3,275)$ berhubungan bermakna dengan kejadian hipertensi. Asupan Na tidak berhubungan bermakna dengan hipertensi pada suku asli Papua, sebaliknya dengan suku non-Papua $(\mathrm{OR}=2,531)$. Terdapat hubungan yang bermakna antara asupan $\mathrm{K}$ dan konsumsi alkohol dengan hipertensi pada suku asli Papua $(\mathrm{OR}=2,348 ; \mathrm{OR}=2,343)$ dan sebaliknya dengan suku non-Papua. Analisis multivariat menunjukkan faktor yang berkontribusi terhadap kejadian hipertensi pada suku asli Papua antara lain stres psikososial, konsumsi alkohol, riwayat keluarga hipertensi, dan asupan K sedangkan pada suku non-Papua yaitu asupan lemak, Na, dan obesitas. Simpulan: Suku nonPapua cenderung terkena hipertensi stage 2 dibanding suku asli Papua. Pada suku asli Papua, asupan lemak lebih ( $>30 \%)$, asupan $\mathrm{K}$ yang kurang $(<2000 \mathrm{mg})$, dan konsumsi alkohol berlebihan $(\geq 2$ gelas per hari) merupakan faktor risiko hipertensi. Pada suku non-Papua, asupan lemak lebih $(>30 \%)$ dan asupan $\mathrm{Na}$ lebih $(\geq 2300 \mathrm{mg})$ merupakan faktor risiko hipertensi.
\end{abstract}

KATA KUNCI: hipertensi, asupan lemak, asupan natrium, asupan kalium, konsumsi alkohol, suku asli Papua dan non-Papua

\footnotetext{
Korespondensi: Gg. Jati VI / 9 A Perumnas II Waena, Jayapura, Papua, e-mail: Sarnibela_26@yahoo.com

2 Sub Bagian Ginjal dan Hipertensi Bagian Ilmu Penyakit Dalam Fakultas Kedokteran Universitas Gadjah Mada / Rumah Sakit Umum Pusat Dr. Sardjito, Jl. Farmako, Sekip Utara, Yogyakarta 55281

3 Jurusan Gizi, Politeknik Kesehatan Kementerian Kesehatan Yogyakarta, Jl. Tata Bumi No. 3, Banyuraden Gamping, Sleman, Yogyakarta
} 


\section{PENDAHULUAN}

Hipertensi merupakan salah satu masalah medis dan kesehatan masyarakat yang mengalami peningkatan prevalensi dan dapat meningkatkan risiko penyakit kardiovaskuler (1). Prevalensi hipertensi di Indonesia berkisar antara 5-15\%. Angka prevalensi hipertensi pada usia kurang dari 40 tahun masih di bawah $10 \%$, tetapi usia di atas 50 tahun mencapai 20\% (2). Prevalensi hipertensi di Provinsi Papua sebesar 22\%. Kota Jayapura memiliki prevalensi sebesar 23,8\% (3). Data sekunder Rumah Sakit Umum Daerah (RSUD) Abepura Kota Jayapura tahun 2008 menunjukkan bahwa penyakit hipertensi berada pada urutan ke-enam di antara 10 besar penyakit pada pasien rawat jalan.

Penelitian sebelumnya menyimpulkan faktor risiko kejadian hipertensi antara lain umur, jenis kelamin, tingkat pendidikan, pekerjaan, tingkat penghasilan, jumlah anak, faktor makanan, dan stres (4). Kejadian hipertensi yang diderita sekitar 43 juta penduduk Amerika Serikat dipengaruhi oleh ras/suku, usia, keadaan geografis, jenis kelamin, dan status sosial ekonomi. Faktor risiko lain yang juga dapat meningkatkan tekanan darah antara lain obesitas, resistensi insulin, konsumsi alkohol yang tinggi, asupan garam yang tinggi (pada pasien yang sensitif terhadap garam), asupan kalium, dan kalsium yang rendah, serta stres (5).

Penduduk Kota Jayapura terdiri dari suku asli Papua dan suku non-Papua. Semua suku yang ada di Kota Jayapura hidup dengan berbagai budaya masingmasing yang beragam (6). Kebudayaan pada setiap suku dari suatu kelompok masyarakat mempunyai kekuatan yang sangat berpengaruh dalam pemilihan konsumsi bahan makanan (7). Pada umumnya, masyarakat suku asli Papua mengonsumsi pangan lokal seperti sagu, keladi, dan ubi jalar. Jenis daging yang dikonsumsi adalah daging babi dan hewan buruan lainnya (daerah pegunungan). Pada masyarakat pesisir pantai, lebih banyak yang mengonsumsi ikan. Saat ini, suku nonPapua banyak yang memiliki usaha dalam bisnis rumah makan. Jenis makanannya disesuaikan dengan asal suku masing-masing yang biasanya menyajikan makanan yang mengandung lemak atau kolesterol, natrium, dan kalium. Oleh karena sudah banyak suku asli Papua di Kota Jayapura yang tinggal membaur dengan suku non-
Papua, maka tidak jarang ditemukan suku asli Papua yang juga mengonsumsi jenis makanan yang berasal dari suku non-Papua.

Data pola konsumsi dari Biro Pusat Statistik (BPS) tahun 2006 untuk Provinsi Papua menunjukkan adanya peningkatan ketersediaan lemak jika dibandingkan dengan tahun 2005. Ketersediaan lemak di tahun 2006 meningkat dari 35,63 gr/kapita/hari menjadi 38,36 gr/ kapita/hari (8). Berdasarkan hasil riset kesehatan dasar (Riskesdas), konsumsi sayur dan buah yang merupakan sumber kalium pada penduduk Kota Jayapura masih kurang dengan prevalensi sebesar 89,6\%. Persentase peminum alkohol untuk jenis minuman whiskey atau vodka adalah sebesar $65,7 \%$, jenis minuman tradisional (saguer) 9\%, dan bir sebesar 25,4\% (3). Konsumsi alkohol yang berlebihan pada dasarnya dapat meningkatkan tekanan dan denyut jantung akibat meningkatnya aktivitas saraf parasimpatik (9).

Pola makan dari seluruh penduduk Kota Jayapura ini, jika ditinjau dari faktor risiko hipertensi bisa menambah tingginya prevalensi hipertensi di Kota Jayapura. Hal ini juga didukung oleh faktor ras atau suku yang melekat pada suku asli Papua. Disebutkan bahwa tekanan darah tinggi lebih banyak diderita oleh orang kulit hitam (Negro) dibandingkan orang kulit putih. Hal ini kemungkinan disebabkan perbedaan genetik pada orang kulit putih dalam hal plasma renin, diuretik, dan beta blockers. Penelitian hipertensi yang berhubungan dengan pola makan pada suku asli Papua dan non-Papua belum pernah dilakukan, oleh karena itu penelitian ini bertujuan untuk menganalisis pola makan (asupan lemak, natrium, kalium, dan konsumsi alkohol) pada suku asli Papua dan non-Papua sebagai faktor risiko kejadian hipertensi di Kota Jayapura.

\section{BAHAN DAN METODE}

Penelitian ini merupakan penelitian observasional analitik dengan rancangan kasus kontrol. Perbandingan kasus dan kontrol adalah 1:1. Kasus adalah semua pasien penderita hipertensi (suku asli Papua dan nonPapua) yang datang berobat (pasien baru dan lama) dan didiagnosis oleh dokter di Poliklinik Penyakit Dalam Rumah Sakit Umum Daerah (RSUD) Abepura serta memenuhi kriteria inklusi dan ekslusi. Kontrol adalah 
pasien dengan diagnosis dokter tidak menderita atau bukan merupakan penderita hipertensi (suku asli Papua dan non-Papua) yang berobat di RSUD Abepura sebagai pembanding kasus setelah melalui proses penyetaraan umur dan jenis kelamin serta telah memenuhi kriteria inklusi dan ekslusi. Kriteria inklusi yaitu bertempat tinggal di Kota Jayapura minimal 3 bulan, berusia antara 18-60 tahun, dan bersedia berpartisipasi dalam penelitian. Kriteria eksklusi antara lain menderita diabetes mellitus, penyakit jantung, atau ibu hamil.

Jumlah subjek pada kelompok kasus dan kontrol untuk suku asli Papua dan non-Papua masing-masing berjumlah 62 orang berdasarkan rumus pengambilan subjek dengan power of test sebesar $80 \%$; tingkat kepercayaan $95 \%$; odds ratio (OR) sebesar 2; dan paparan pada kelompok kontrol (p2) sebesar 0,4 (10) sehingga total subjek (kasus dan kontrol) keseluruhan untuk suku asli Papua dan non-Papua berjumlah 248 orang. Pengambilan subjek dengan cara non-random sampling (by accidental sampling). Penelitian dilaksanakan di RSUD Abepura Kota Jayapura pada bulan Januari - Maret 2010.

Variabel yang diukur pada penelitian ini terdiri dari variabel dependen yaitu kejadian hipertensi pada suku asli Papua dan non-Papua. Variabel independen yaitu pola makan yang meliputi asupan lemak, natrium, kalium, dan konsumsi alkohol. Variabel luar antara lain aktivitas fisik, merokok, stres psikososial, riwayat keluarga yang menderita hipertensi, konsumsi kopi, alat kontrasepsi hormonal, dan obesitas untuk melihat pengaruhnya sebagai confounding factor.

Subjek (kelompok kasus) dikatakan hipertensi apabila tekanan darah subjek lebih dari atau sama dengan 140/90 mmHg. Derajat hipertensi merupakan tingkatan hipertensi yang diklasifikasikan berdasarkan Joint National Committee (JNC) VII 2004 dengan klasifikasi hipertensi stage 1 jika tekanan darah sistolik antara 140-159 mmHg dan tekanan darah diastolik antara 90-99 mmHg sedangkan hipertensi stage 2 jika tekanan darah sistolik lebih dari atau sama dengan $160 \mathrm{mmHg}$ dan tekanan darah diastolik lebih dari atau sama dengan $100 \mathrm{mmHg}$. Pengukuran tekanan darah menggunakan mercurial sphygmomanometer yang dilakukan oleh tenaga perawat sebanyak 2 kali pada posisi duduk tegak selama 5 menit.
Asupan lemak adalah konsumsi rata-rata lemak dibandingkan dengan proporsi lemak terhadap angka kecukupan energi (AKG) berdasarkan jumlah energi 2.250 $\mathrm{kkal} /$ hari untuk laki-laki dan $1.750 \mathrm{kkal} /$ hari untuk wanita. Asupan lemak kemudian dikategorikan menjadi lebih jika asupan lemak lebih dari 30\% total kalori; cukup jika asupan lemak di antara 20-30\% total kalori; dan kurang jika asupan lemak kurang dari 20\% total kalori. Asupan natrium ( $\mathrm{Na}$ ) adalah konsumsi rata-rata Na per hari dengan kriteria lebih ( $\geq 2300 \mathrm{mg}$ ) dan kurang (<2300 mg) (11). Demikian juga dengan asupan kalium (K) yaitu konsumsi rata-rata kalium per hari dengan kriteria lebih ( $\geq 2000 \mathrm{mg}$ ) dan kurang (< $2000 \mathrm{mg}$ ) (11). Konsumsi alkohol dikategorikan berdasarkan perkiraan volume gelas yang dikonsumsi yaitu subjek dikategorikan konsumsi alkohol jika mengonsumsi lebih dari atau sama dengan 2 gelas per hari sedangkan subjek dikategorikan tidak mengkonsumsi jika konsumsi alkohol kurang dari 2 gelas per hari atau tidak pernah mengonsumsi alkohol sama sekali (12).

Lebih lanjut, variabel aktivitas fisik dibedakan menjadi dua kategori yaitu adekuat dan tidak adekuat. Dikategorikan adekuat jika aktivitas fisik/latihan dilakukan lebih dari atau sama dengan 3 kali seminggu dengan lama aktivitas/latihan lebih dari atau sama dengan 30 menit. Stres psikososial adalah semua keadaan perubahan baik secara fisik mental maupun sosial dari seseorang akibat adanya tekanan psikososial. Stres psikososial diukur dengan social readjustment rating scale (13) dengan kriteria stres jika jumlah "stress points" lebih dari atau sama dengan 300 poin. Pengukuran berat badan dan tinggi badan menggunakan timbangan injak dan microtoise untuk mengetahui indeks massa tubuh (IMT) yang kemudian dikategorikan obesitas jika IMT lebih dari atau sama dengan $25 \mathrm{~kg} / \mathrm{m}^{2}$.

Data primer yang diambil antara lain karakteristik subjek (jenis kelamin, usia, tingkat pendidikan, jenis pekerjaan), tekanan darah, tinggi badan dan berat badan (untuk penentuan IMT), serta data faktor-faktor risiko hipertensi termasuk konsumsi alkohol yang ditanyakan menggunakan kuesioner. Food frequency questionnaire (FFQ) digunakan untuk menanyakan pola asupan makan subjek (lemak, natrium, kalium) selama 3 bulan terakhir dengan bantuan food model yang kemudian diolah dalam software nutrisurvey. Pengambilan data penelitian ini 
Tabel 1. Distribusi karakteristik subjek penelitian

\begin{tabular}{|c|c|c|c|c|c|c|c|c|}
\hline \multirow[b]{2}{*}{ Variabel } & \multicolumn{4}{|c|}{ Suku asli Papua } & \multicolumn{4}{|c|}{ Suku non-Papua } \\
\hline & $\begin{array}{c}\text { Kasus } \\
(\%)\end{array}$ & $\begin{array}{c}\text { Kontrol } \\
(\%)\end{array}$ & p & $95 \% \mathrm{CI}$ & $\begin{array}{c}\text { Kasus } \\
(\%)\end{array}$ & $\begin{array}{c}\text { Kontrol } \\
(\%)\end{array}$ & $\mathbf{p}$ & $95 \% \mathrm{CI}$ \\
\hline \multicolumn{9}{|l|}{ Jenis kelamin } \\
\hline Laki-laki & $20(32,2)$ & $20(32,2)$ & 1,000 & $0,471-2,123$ & $24(38,7)$ & $24(38,7)$ & 1,000 & $0,485-2,060$ \\
\hline Perempuan & $42(67,7)$ & $42(67,7)$ & & & $38(61,3)$ & $38(61,3)$ & & \\
\hline \multicolumn{9}{|l|}{ Umur (tahun) } \\
\hline Muda $(\leq 46)$ & $32(51,6)$ & $32(51,6)$ & 1,000 & $0,527-2,157$ & $28(45,2)$ & $28(45,2)$ & 0,717 & $0,598-2,485$ \\
\hline Tua $(>46)$ & $30(48,4)$ & $30(48,4)$ & & & $34(54,8)$ & $34(54,8)$ & & \\
\hline \multicolumn{9}{|l|}{ Pendidikan } \\
\hline Rendah(<SLTA) & $27(43,5)$ & $28(45,2)$ & 0,857 & $0,461-1,903$ & $18(29,0)$ & $19(30,6)$ & 0,844 & $0,429-1,999$ \\
\hline Tinggi ( $\geq$ SLTA) & $35(56,5)$ & $34(54,8)$ & & & $44(71,0)$ & $43(69,4)$ & & \\
\hline \multicolumn{9}{|l|}{ Pekerjaan } \\
\hline PNS & $14(22,6)$ & $12(19,6)$ & & & $19(30,6)$ & $14(22,6)$ & & \\
\hline Wiraswasta & $8(12,9)$ & $12(9,6)$ & & & $10(16,1)$ & $19(30,6)$ & & \\
\hline Petani & $6(9,7)$ & $8(12,9)$ & 0,563 & - & $1(1,6)$ & $2(3,2)$ & 0,105 & - \\
\hline IRT & $28(45,2)$ & $28(45,2)$ & & & $25(40,3)$ & $18(29,0)$ & & \\
\hline Pegawai swasta & $4(6,5)$ & $2(3,2)$ & & & $3(4,8)$ & $8(12,9)$ & & \\
\hline Lain-lain & $2(3,2)$ & 0 & & & $4(6,5)$ & $1(1,6)$ & & \\
\hline
\end{tabular}

Keterangan: PNS=pegawai negeri sipil; SLTA=sekolah lanjutan tingkat atas; IRT=ibu rumah tangga

dibantu oleh tenaga enumerator dengan kualifikasi S1 gizi sebanyak 2 orang, D3 Gizi sebanyak 3 orang, perawat sebanyak 3 orang, dan 1 orang dokter. Penelitian ini telah memperoleh ethical clearance dari Komite Etik Penelitian Kedokteran Kesehatan Universitas Gadjah Mada.

Analisis univariat dilakukan dengan menyajikan distribusi frekuensi dari karakteristik subjek serta variabel-variabel yang diteliti. Independent sample t-test digunakan untuk melihat perbedaan rerata asupan lemak, asupan natrium, dan asupan kalium. Analisis bivariat dilakukan dengan menggunakan uji Chi-Square untuk melihat pengaruh variabel independen terhadap variabel dependen serta melihat perbedaan derajat hipertensi antara suku asli Papua dan non-Papua. Analisis multivariat dilakukan dengan menggunakan uji MaentelHaenszel untuk mengetahui variabel luar lainnya yang berpotensi sebagai confounding. Analisis regresi logistik ganda sebagai kelanjutan uji statistik Maentel-Haenszel jika terbukti sebagai faktor confounding.

\section{HASIL}

\section{Karakteristik subjek penelitian}

Kejadian hipertensi (kelompok kasus) pada suku asli Papua dan non-Papua lebih banyak pada mereka yang berjenis kelamin perempuan. Pada suku asli Papua, kejadian hipertensi (kelompok kasus) lebih banyak terjadi pada usia muda ( $<45$ tahun) sebaliknya dengan suku non-Papua ( $>45$ tahun). Sebagian besar subjek baik pada suku asli Papua dan non-Papua memiliki tingkat pendidikan tinggi ( $\geq$ SLTA). Kejadian hipertensi pada suku asli Papua dan non-Papua lebih banyak ditemukan pada subjek yang bekerja sebagai ibu rumah tangga (IRT) (Tabel 1).

Hasil analisis statistik secara keseluruhan menunjukkan bahwa antara suku asli Papua dan nonPapua tidak terdapat perbedaan yang bermakna terhadap derajat hipertensi stage 1 dan stage $2(\mathrm{p}>0,05)$. Diketahui pula bahwa kejadian hipertensi stage 2 (sistolik $\geq$ $160 \mathrm{mmHg}$ dan diastolik $\geq 100 \mathrm{mmHg}$ ) lebih banyak ditemukan pada subjek yang berasal dari suku nonPapua dibandingkan dengan subjek dari suku asli Papua (Tabel 2).

Tabel 2. Perbedaan derajat hipertensi antarsuku asal subjek

\begin{tabular}{|c|c|c|c|c|c|}
\hline \multirow{2}{*}{$\begin{array}{c}\text { Derajat } \\
\text { hipertensi }\end{array}$} & \multicolumn{2}{|c|}{ Suku asal subjek } & \multirow[b]{2}{*}{ OR } & \multirow[b]{2}{*}{$95 \%$ CI } & \multirow[b]{2}{*}{$\mathbf{p}$} \\
\hline & $\begin{array}{c}\text { Asli } \\
\text { Papua } \\
\end{array}$ & $\begin{array}{c}\text { Non- } \\
\text { Papua }\end{array}$ & & & \\
\hline Stage 1 & 39 & 29 & \multirow{2}{*}{1,930} & \multirow{2}{*}{$0,942-3,943$} & \multirow{2}{*}{0,071} \\
\hline Stage 2 & 23 & 33 & & & \\
\hline
\end{tabular}


Tabel 3. Pola makan dan konsumsi alkohol sebagai faktor risiko terjadinya hipertensi pada suku asli Papua dan nonPapua

\begin{tabular}{|c|c|c|c|c|c|c|c|c|c|c|}
\hline \multirow[b]{2}{*}{ Variabel } & \multicolumn{5}{|c|}{ Suku asli Papua } & \multicolumn{5}{|c|}{ Suku non-Papua } \\
\hline & $\begin{array}{c}\text { Kasus } \\
(\%)\end{array}$ & $\begin{array}{c}\text { Kontrol } \\
(\%)\end{array}$ & OR & $95 \%$ CI & $\mathbf{p}$ & $\begin{array}{c}\text { Kasus } \\
(\%)\end{array}$ & $\begin{array}{c}\text { Kontrol } \\
(\%)\end{array}$ & OR & $95 \%$ CI & $\mathbf{p}$ \\
\hline \multicolumn{11}{|l|}{ Lemak (\%) } \\
\hline Lebih (> 30) & $38(61,3)$ & $19(30,6)$ & 3,250 & $1,150-9,183$ & $0,023^{*}$ & $33(53,2)$ & $22(35,5)$ & 3,273 & $1,338-8,006$ & $0,008^{*}$ \\
\hline Cukup (20-30) & $16(25,8)$ & $30(48,4)$ & 0,867 & $0,297-2,525$ & 0,793 & $18(29,0)$ & $16(19,4)$ & 2,455 & $0,920-6,548$ & 0,070 \\
\hline Kurang $(<20)$ & $8(12,9)$ & $13(21,0)$ & 1,000 & references & & $11(17,7)$ & $24(38,7)$ & 1,000 & references & \\
\hline \multicolumn{11}{|l|}{ Natrium (mg) } \\
\hline Lebih $(\geq 2300)$ & $58(93,5)$ & $56(90,3)$ & 1,554 & $0,416-5,800$ & 0,510 & $35(56,5)$ & $21(33,9)$ & 2,531 & $1,223-5,236$ & $0,012 *$ \\
\hline Kurang $(<2300)$ & $4(6,5)$ & $6(9,7)$ & 1,000 & references & & $27(43,5)$ & $41(66,1)$ & 1,000 & references & \\
\hline \multicolumn{11}{|l|}{ Kalium (mg) } \\
\hline Kurang $(<2000)$ & $39(62,9)$ & $26(41,9)$ & 2,348 & $1,142-4,829$ & $0,019^{*}$ & $28(45,2)$ & $24(38,7)$ & 1,304 & $0,638-2,666$ & 0,467 \\
\hline Lebih $(\geq 2000)$ & $23(37,1)$ & $36(58,1)$ & 1,000 & references & & $34(54,8)$ & $38(61,3)$ & 1,000 & references & \\
\hline \multicolumn{11}{|l|}{ Alkohol } \\
\hline Konsumsi & $37(59,7)$ & $24(38,7)$ & 2,343 & $1,140-4,815$ & $0,020^{*}$ & $1(1,6)$ & $1(1,6)$ & 1,000 & $0,061-16,353$ & 0,100 \\
\hline Tidak konsumsi & $25(40,3)$ & $38(61,3)$ & 1,000 & references & & $61(98,4)$ & $61(98,4)$ & 1,000 & references & \\
\hline
\end{tabular}

Keterangan: *bermakna $(\mathrm{p}<0,05)$

\section{Analisis bivariat}

Secara teori, subjek berisiko hipertensi jika memiliki asupan lemak lebih $(>30 \%)$, asupan $\mathrm{Na}$ berlebih ( $\geq 2300 \mathrm{mg}$ ), asupan K kurang (<2000 mg), dan mengonsumsi alkohol ( $\geq 2$ gelas per hari). Hasil analisis menunjukkan bahwa secara keseluruhan antara suku asli Papua dan non-Papua terlihat adanya perbedaan distribusi subjek terhadap asupan lemak, Na, K, dan konsumsi alkohol. Pada subjek yang hipertensi (kasus), variabel asupan lemak lebih, asupan $\mathrm{Na}$ berlebih, asupan K kurang, dan konsumsi alkohol cenderung lebih banyak ditemukan pada suku asli Papua dibandingkan suku nonPapua (Tabel 3).

Pada suku asli Papua terdapat hubungan yang bermakna antara asupan lemak lebih (> 30\%) dengan kejadian hipertensi. Subjek yang memiliki asupan lemak lebih cenderung berisiko 3,25 kali lebih tinggi untuk terkena hipertensi dibanding yang memiliki asupan lemak kurang $(<20 \%)$. Demikian juga pada suku nonPapua yang menunjukkan hubungan bermakna antara asupan lemak dan kejadian hipertensi. Subjek yang memiliki asupan lemak lebih cenderung berisiko 3,273 kali lebih tinggi terkena hipertensi dibanding asupan lemak kurang.

Berbeda dengan asupan Na pada suku asli Papua yang secara statistik tidak memiliki hubungan bermakna terhadap kejadian hipertensi, meskipun ada kecenderungan pada subjek yang memiliki asupan $\mathrm{Na}$ berlebih $(\geq 2300$ mg) untuk terkena hipertensi 1,5 kali lebih besar bila dibandingkan dengan subjek yang memiliki asupan $\mathrm{Na}$ kurang. Sebaliknya, pada suku non-Papua memiliki hubungan bermakna dengan kecenderungan subjek yang memiliki asupan $\mathrm{Na}$ berlebih berisiko 2,5 kali untuk terkena hipertensi bila dibandingkan subjek dengan asupan $\mathrm{Na}$ yang kurang.

Lebih lanjut, hasil analisis untuk asupan $\mathrm{K}$ dan konsumsi alkohol pada suku asli Papua menunjukkan hubungan yang bermakna dengan kejadian hipertensi. Subjek dengan asupan K yang kurang dan mengonsumsi alkohol ( $\geq 2$ gelas per hari) memiliki kecenderungan sebesar 2,35 kali dan 2,34 kali lebih tinggi untuk terkena hipertensi dibandingkan subjek dengan asupan K kurang dan tidak mengonsumsi alkohol. Berbeda dengan suku non-Papua yang secara statistik menunjukkan bahwa asupan $\mathrm{K}$ dan konsumsi alkohol tidak berhubungan dengan kejadian hipertensi (Tabel 3).

Hasil analisis pengaruh variabel luar terhadap hipertensi pada suku asli Papua dan non-Papua menunjukkan bahwa riwayat keluarga yang menderita hipertensi dan stres psikososial pada suku asli Papua memiliki hubungan yang bermakna terhadap kejadian hipertensi. Subjek yang memiliki riwayat keluarga hipertensi dan mengalami stres psikososial cenderung berisiko 3,805 kali dan 2,348 kali untuk terkena hipertensi 
Tabel 4. Faktor yang berpengaruh dominan terhadap kejadian hipertensi pada suku asli Papua dan Non-Papua

\begin{tabular}{cclccc}
\hline Suku asal & Model & \multicolumn{1}{c}{ Variabel } & $\mathbf{E x p}(\mathbf{B})$ & $\mathbf{9 5 \%}$ CI & Sig \\
\hline Asli Papua & 1 & Asupan lemak lebih & 2,59 & $0,770-8,740$ & 0,124 \\
& & Asupan kalium & 2,24 & $0,941-5,328$ & 0,068 \\
& & Konsumsi alkohol & 5,38 & $1,976-14,692$ & $0,001^{*}$ \\
& & Riwayat hipertensi & 4,59 & $1,852-11,375$ & $0,001^{*}$ \\
& \multirow{2}{*}{2} & Stres psikososial & 4,41 & $1,636-11,894$ & $0,003^{*}$ \\
& & Asupan kalium & 2,28 & $1,005-5,211$ & $0,049^{*}$ \\
& & Konsumsi alkohol & 4,58 & $1,766-11,890$ & $0,002^{*}$ \\
& & Riwayat hipertensi & 4,31 & $1,845-10,090$ & $0,001^{*}$ \\
Non-Papua & \multirow{2}{*}{1} & Stres psikososial & 5,20 & $1,974-13,722$ & $0,001^{*}$ \\
& & Asupan lemak lebih & 3,30 & $1,272-8,596$ & $0,014^{*}$ \\
& & Asupan natrium & 3,11 & $1,410-6,894$ & $0,005^{*}$ \\
& & Obesitas & 2,38 & $1,085-5,219$ & $0,030^{*}$ \\
\hline
\end{tabular}

dibandingkan yang tidak memiliki riwayat keluarga dan tidak mengalami stres psikososial. Sementara itu, hasil analisis pada suku non-Papua menunjukkan bahwa hanya variabel obesitas yang memiliki hubungan bermakna dengan kejadian hipertensi. Subjek yang obesitas, cenderung berisiko 2,192 kali untuk terkena hipertensi dibandingkan yang tidak obesitas. Variabel luar berupa riwayat keluarga yang hipertensi dan stres psikososial pada suku asli Papua serta variabel obesitas pada suku non-Papua akan dianalisis lebih lanjut dengan Maentel Haenszel untuk membuktikan potensi sebagai confounding factor.

\section{Analisis multivariat}

Analisis Maentel-Haenszel dilakukan untuk membuktikan adanya faktor lain (variabel luar) yang mengganggu (confounding factor) hubungan variabel bebas (secara statistik tidak bermakna; $p>0,05$ ) dengan variabel terikat. Pada suku asli Papua, hasil analisis bivariat (Tabel 3) diperoleh bahwa asupan Na tidak berhubungan bermakna dengan kejadian hipertensi $(p=0,51)$ sehingga dicurigai variabel riwayat keluarga yang hipertensi dan stres psikososial sebagai faktor confounding pada hubungan $\mathrm{Na}$ dengan hipertensi. Hasil analisis Maentel-Haenszel menunjukkan bahwa variabel riwayat keluarga yang hipertensi merupakan faktor confounding (pengganggu) pada hubungan antara asupan $\mathrm{Na}$ dan hipertensi pada suku asli Papua dengan selisih Crude Odds Ratio (COR) dan Maentel-Haenzel Odds
Ratio (MOR) lebih dari 20\% (33\%) sehingga riwayat keluarga yang hipertensi dilanjutkan pada analisis regresi logistik berganda. Sebaliknya, variabel stres psikososial bukan merupakan faktor confounding pada hubungan asupan Na dengan hipertensi pada suku asli Papua (selisih COR dan MOR < 20\% yaitu 3\%).

Sementara itu, pada suku non-Papua, analisis bivariat menunjukkan bahwa asupan $\mathrm{K}$ dan konsumsi alkohol tidak berhubungan bermakna dengan kejadian hipertensi (Tabel 3). Variabel obesitas dicurigai sebagai faktor confounding pada hubungan asupan $\mathrm{K}$ dengan hipertensi dan juga pada hubungan konsumsi alkohol dengan hipertensi. Hasil analisis Maentel-Haenszel menunjukkan bahwa variabel obesitas bukan merupakan faktor confounding pada hubungan asupan $\mathrm{K}$ dengan hipertensi pada suku non-Papua (selisih COR dan MOR < $20 \%$ yaitu 1\%). Sebaliknya, variabel obesitas merupakan faktor confounding (pengganggu) pada hubungan konsumsi alkohol dengan hipertensi (selisih COR dan MOR $>20 \%$ yaitu 52\%) sehingga variabel obesitas ikut dilanjutkan pada analisis regresi logistik berganda.

Selanjutnya, untuk mengetahui faktor yang paling dominan berpengaruh terhadap terjadinya hipertensi digunakan analisis regresi logistik berganda. Variabel yang diikutsertakan pada analisis ini adalah yang memiliki nilai $\mathrm{p}$ kurang dari 0,05 serta yang menjadi faktor confounding. Hasil akhir model regresi logistik menunjukkan faktor yang berkontribusi terhadap terjadinya hipertensi pada suku asli Papua adalah variabel asupan kalium, konsumsi alkohol, riwayat 
keluarga hipertensi, dan stres psikososial. Variabel stres psikososial pada suku asli Papua merupakan faktor yang paling berkontribusi terhadap terjadinya hipertensi (Exp.B $=5,20)$ dan konsumsi alkohol menjadi faktor kedua yang berkontribusi terhadap terjadinya hipertensi (Exp.B=4,58). Sementara itu, pada suku non-Papua variabel yang masuk pada model regresi logistik antara lain variabel asupan lemak, asupan $\mathrm{Na}$, dan obesitas. Setelah dianalisis secara bersamaan, variabel asupan lemak berlebih paling berkontribusi terhadap terjadinya hipertensi pada suku non-Papua (Exp. $\mathrm{B}=3,30$ ) diikuti variabel asupan $\mathrm{Na}$ (Exp.B=3,11) dan obesitas merupakan variabel yang paling kecil berkontribusi terhadap terjadinya hipertensi (Exp.B=2,38) (Tabel 4).

\section{BAHASAN}

Subjek yang menderita hipertensi (kasus) pada suku asli Papua dan non-Papua lebih banyak yang berjenis kelamin perempuan, tetapi hasil analisis tidak menunjukkan adanya perbedaan yang bermakna. Secara keseluruhan, subjek yang diperoleh adalah yang bertempat tinggal di daerah sekitar Kota Jayapura. Perempuan suku asli Papua yang tinggal di daerah perkotaan harus berjuang untuk menghidupi keluarganya, meskipun sebagian besar subjek perempuan adalah ibu rumah tangga (IRT). Hal ini bisa menambah beban pikiran (stres) yang menyebabkan tingginya tekanan darah jika ditunjang dengan faktor risiko lainnya yaitu dari segi makanan (diet). Hal ini sejalan dengan beberapa penelitian sebelumnya yang menyimpulkan bahwa penderita hipertensi lebih banyak yang berjenis kelamin perempuan (14-16).

Berdasarkan umur, subjek yang hipertensi pada suku asli Papua lebih banyak yang berusia kurang dari 46 tahun. Sebaliknya, pada suku non-Papua, subjek yang hipertensi lebih banyak yang berusia lebih dari 46 tahun. Terlihat bahwa kejadian hipertensi di usia kurang dari 46 tahun pada suku asli Papua karena rerata usia tersebut masih dalam usia produktif sehingga secara tidak langsung berhubungan dengan tekanan beban hidup yang mengharuskan untuk tetap bekerja. Pada suku non-Papua, subjek yang hipertensi justru yang berusia lebih dari 46 tahun. Jika dihubungkan dengan jenis kelamin perempuan maka umur tersebut adalah ratarata usia wanita menopause.
Menurut teori, meningkatnya insiden hipertensi pada wanita adalah pada saat memasuki fase menopause (17). Masa menstruasi atau masa sebelum menopause, mengakibatkan volume cairan dalam tubuh tetap terjaga sehingga aliran atau tekanan hemodinamik (frekuensi nadi) tetap melambat sehingga insiden hipertensi masih rendah. Wanita yang belum menopause tetapi telah menderita hipertensi didapati kadar hormon estrogennya lebih tinggi dibandingkan wanita yang tidak hipertensi. Penelitian pada populasi umum di Amerika serikat juga menunjukkan hasil yang sama yaitu proporsi kasus hipertensi terbanyak adalah pada subjek yang berumur 45-64 tahun dan berkurang pada usia lebih dari 75 tahun (18). Penelitian pada masyarakat tradisional Melanesia di Papua New Guinea, tekanan darah sistolik mengalami peningkatan secara linear setelah usia 50 tahun pada pria dan wanita (19).

Berdasarkan tingkat pendidikan, diperoleh bahwa subjek yang hipertensi lebih banyak yang memiliki tingkat pendidikan lebih dari atau setingkat SLTA pada suku asli Papua maupun non-Papua. Hal ini secara tidak langsung menunjukkan bahwa semakin tinggi tingkat pendidikan, justru lebih meningkatkan kejadian hipertensi pada kedua suku. Faktor kurangnya pengetahuan dan kesadaran diri untuk lebih peduli dan memperhatikan berbagai hal yang berhubungan dengan penyakit hipertensi diduga sebagai penyebab terjadinya hipertensi walaupun banyak dari mereka yang sudah memiliki pendidikan tinggi. Penelitian pada lanjut usia di Belanda membuktikan bahwa hipertensi lebih banyak terjadi di antara pria yang memiliki pendidikan yang tinggi dan pada wanita yang memiliki tingkat pendidikan rendah (20).

Hasil analisis menunjukkan bahwa suku nonPapua cenderung berisiko 1,9 kali terkena hipertensi stage 2 (tekanan darah sistolik $\geq 160 \mathrm{mmHg}$ dan tekanan darah diastolik $\geq 100 \mathrm{mmHg}$ ) dibanding suku asli Papua. Kecenderungan terjadinya hipertensi stage 2 pada suku non-Papua lebih didasarkan dari segi budaya yang didalamnya terdapat pola makan. Pengaruh asupan lemak dan Na yang berlebihan menjadi penyebab banyaknya kasus yang memiliki derajat hipertensi stage 2. Pada suku non-Papua, kemudahan dalam mengonsumsi makanan tinggi lemak dan tinggi Na yang akan menuju pada keadaan obesitas. Pada analisis multivariat regresi 
logistik ganda, variabel obesitas merupakan salah satu faktor luar yang berkontribusi untuk terjadinya hipertensi pada suku non-Papua. Hal inilah yang menyebabkan suku non-Papua lebih cenderung menderita hipertensi stage 2 dibandingkan suku asli Papua (stage 1). Kecenderungan terjadinya hipertensi stage 1 pada suku asli Papua lebih didasarkan pada pola makan termasuk konsumsi alkohol dan dari faktor luar lainnya. Setelah melalui analisis multivariat regresi logistik ganda, didapatkan hasil bahwa pola makan yang berkontribusi dalam terjadinya hipertensi pada suku asli Papua adalah asupan K dan konsumsi alkohol. Faktor luar yang berkontribusi adalah riwayat keluarga yang hipertensi dan stres psikososial.

Penelitian pada orang perkotaan di daerah India menunjukkan bahwa orang yang berusia lebih dari 40 tahun mempunyai risiko yang bermakna untuk terkena hipertensi stage 1 dan stage 2. Sementara orang dengan usia 40-49 tahun berisiko 4 kali untuk terkena hipertensi stage 2, usia antara 50-59 tahun memiliki risiko 8 kali, dan yang berusia lebih dari 60 tahun berisiko 14 kali untuk terkena hipertensi stage 2 (21). Berbagai faktor lingkungan seperti faktor diet (terutama asupan Na yang tinggi, rendah $\mathrm{K}$ dan kalsium) dapat mempengaruhi perbedaan tekanan darah pada ras kulit hitam dan kulit putih (22). Terjadinya hipertensi pada kulit hitam disebabkan rendahnya asupan $\mathrm{K}$, rendahnya aktivitas fisik, tingginya faktor tekanan psikososial, dan besarnya sensitivitas terhadap asupan garam (23).

Lebih lanjut, berdasarkan wawancara dengan FFQ diketahui bahwa asupan lemak pada suku asli Papua diperoleh dari konsumsi daging yaitu daging ayam dan daging babi. Frekuensi konsumsi tidak terlalu sering (jarang) yaitu sekitar 1-2 minggu sekali ataupun hanya pada acara-acara tertentu. Selain itu, dalam pengolahan makanan biasanya dilakukan dengan cara merebus, meskipun sudah ada yang menggunakan minyak setiap harinya dalam mengolah makanan. Pada suku nonPapua, asupan lemak diperoleh dari konsumsi daging yang berupa daging ayam, daging sapi, daging babi, dan daging sumber jeroan. Pengolahan makanan lebih banyak dilakukan dengan menggunakan minyak dalam jumlah yang besar. Keterjangkauan dalam mengonsumsi makanan yang mengandung lemak lebih mudah diperoleh suku non-Papua dibandingkan pada suku asli Papua.
Pada analisis multivariat, asupan lemak pada suku asli Papua bukan merupakan faktor yang berkontribusi untuk terjadinya hipertensi, setelah secara bersamasama dianalisis dengan variabel lainnya yang juga bermakna secara statistik terhadap hipertensi (asupan $\mathrm{K}$, konsumsi alkohol, riwayat keluarga yang hipertensi, stres psikososial). Hal ini menunjukkan bahwa asupan lemak merupakan faktor risiko namun bukan faktor yang paling berkontribusi terhadap terjadinya hipertensi pada suku asli Papua. Sebaliknya pada suku nonPapua, asupan lemak merupakan faktor yang paling berkontribusi terhadap terjadinya hipertensi $(\mathrm{OR}=3,30)$ setelah secara bersama-sama dianalisis dengan variabel lainnya yang juga bermakna terhadap hipertensi (asupan $\mathrm{Na}$ dan obesitas). Dengan demikian, asupan lemak perlu mendapat perhatian yang lebih terutama bila dikonsumsi secara berlebihan, oleh karena merupakan faktor penyebab utama terjadinya hipertensi pada suku non-Papua. Penelitian di Semarang menyimpulkan bahwa asupan lemak berhubungan dengan tekanan darah sistolik. Semakin banyak asupan lemak ( $>30 \%$ ) maka tekanan darah sistolik semakin tinggi. Pada populasi wanita didapatkan bahwa peningkatan 1\% konsumsi lemak dari total kalori, akan meningkatkan tekanan darah sebesar $0,5 \mathrm{mmHg}$ (24).

Pada suku asli Papua, asupan Na secara statistik tidak berhubungan bermakna terhadap kejadian hipertensi. Proporsi kasus (menderita hipertensi) yang memiliki asupan Na berlebih ( $\geq 2300 \mathrm{mg}$ ) hampir sama banyaknya dengan proporsi pada kelompok kontrol (tidak hipertensi). Hal ini diduga yang menyebabkan tidak adanya hubungan yang bermakna terhadap kejadian hipertensi. Rata-rata asupan Na pada suku asli Papua diperoleh dari konsumsi ikan yang diasinkan serta mie instan. Pemakaian bumbu penyedap tidak terlalu banyak digunakan pada suku asli Papua jika dibandingkan dengan suku non-Papua. Makanan kaleng ataupun yang diawetkan juga jarang dikonsumsi oleh suku asli Papua meskipun juga kadangkadang dikonsumsi sehari-hari karena mudah diperoleh dengan harga yang relatif murah (terutama untuk mie instan) dibandingkan makanan sumber Na lainnya.

Sebaliknya, asupan $\mathrm{Na}$ pada suku non-Papua secara statistik berhubungan bermakna dengan kejadian hipertensi. Rata-rata asupan $\mathrm{Na}$ diperoleh dari konsumsi 
makanan sumber jeroan serta pemakaian bumbu penyedap. Frekuensi konsumsi serta penggunaan bahan makanan sumber $\mathrm{Na}$ sering ditemukan setiap harinya. Makanan jadi yang paling banyak dikonsumsi adalah sejenis mie dan makanan siap santap (fast food). Minuman kaleng lebih banyak dikonsumsi hanya pada hari raya dan untuk minuman seperti susu lebih banyak dikonsumsi pada suku non-Papua. Hasil analisis multivariat menunjukkan bahwa asupan $\mathrm{Na}$ pada suku non-Papua juga berkontribusi untuk terjadinya hipertensi $(\mathrm{OR}=3,11)$ setelah dianalisis secara bersamaan dengan variabel asupan lemak dan obesitas sehingga konsumsi berlebihan makanan sumber Na perlu mendapat perhatian terutama pada suku non-Papua. Penelitian pada lansia di Bengkulu mendapatkan hasil bahwa mereka yang hipertensi rata-rata memiliki asupan Na berlebih $(\geq 2300$ $\mathrm{mg}$ ) dan memiliki risiko 3,43 kali terkena hipertensi (25). Penelitian lain menunjukkan penurunan asupan Na sebagai salah satu terapi non-farmakologis pada usia lanjut sangat efektif dalam menurunkan tekanan darah dan mengontrol tekanan darah (26).

Selanjutnya, asupan K pada suku non-Papua tidak menunjukkan hubungan bermakna terhadap kejadian hipertensi. Hal ini disebabkan subjek yang hipertensi (kasus dan kontrol) dengan asupan K berlebih $(\geq 2000$ $\mathrm{mg})$, proporsinya lebih banyak dibanding yang asupannya kurang $(<2000 \mathrm{mg})$. Namun, tidak demikian dengan suku asli Papua yang berdasarkan hasil analisis multivariat menunjukkan hasil bahwa asupan $\mathrm{K}$ merupakan salah satu faktor yang berkontribusi terhadap terjadinya hipertensi. Pada suku asli Papua, sebagian besar kasus memiliki asupan $\mathrm{K}$ yang kurang sehingga asupan $\mathrm{K}$ berhubungan bermakna terhadap kejadian hipertensi. Hal ini disebabkan lebih banyaknya kasus yang mengonsumsi makanan rendah K. Asupan K suku asli Papua diperoleh dari jenis sayuran yang berupa kangkung, daun singkong, bunga pepaya, daun gedi, dan sayur lilin. Sayur yang dikonsumsi tidak terlalu beraneka ragam dan hanya dimakan sesekali saja sedangkan jenis buah yang paling sering dikonsumsi adalah pisang dan mangga.

Suku asli Papua yang tinggal di Kota Jayapura lebih cenderung untuk mengonsumsi makanan pokok sumber karbohidrat (umbi-umbian, nasi, beras, mie) serta makanan hasil laut maupun sumber lemak.
Makanan sumber $\mathrm{K}$ hanya dikonsumsi sebagai makanan pendamping saja dan bukan sebagai makanan utama dalam penyajiannya. Berbeda dengan suku non-Papua, pola makan sudah beraneka ragam dalam hal jenisnya (sayur dan buah) dan dalam setiap penyajian makan selalu disertai dengan makanan sumber K. Fungsi K adalah mengatur keseimbangan jumlah $\mathrm{Na}$ dalam sel (27). Salah satu akibat kekurangan asupan $\mathrm{K}$ adalah menurunnya kemampuan jantung dalam memompa darah (28). Penambahan asupan K akan menurunkan $\mathrm{Na}$ intranse dengan cara aktivasi pompa Na-K-ATP yang akan mengakibatkan pengurangan efek peningkatan tekanan darah oleh karena tingginya asupan $\mathrm{Na}$ (29). Asupan $\mathrm{K}$ bisa diperoleh dari mengonsumsi berbagai sayur dan buah-buahan (28).

Konsumsi alkohol pada suku asli Papua memiliki hubungan yang bermakna terhadap kejadian hipertensi. Konsumsi alkohol pada masyarakat suku asli Papua sudah merupakan hal yang biasa di tengah masyarakat (merupakan budaya). Dikatakan merupakan budaya oleh karena minuman alkohol yang biasa dikonsumsi yaitu saguer sering dijumpai saat merayakan upacara adat, pesta adat, syukuran dan sebagainya. Menurut hasil pengamatan, orang Papua asli paling banyak mengonsumsi saguer oleh karena harganya sangat murah jika dibandingkan dengan minuman beralkohol jenis lain yang beredar di Kota Jayapura (whisky, vodka, dan lainnya). Peredaran minuman beralkohol di Kota Jayapura belum mendapat perhatian penuh dari pemerintah karena berbisnis alkohol memberikan kontribusi yang besar secara ekonomi dalam pendapatan daerah (6). Selain itu, analisis multivariat juga menunjukkan hasil bahwa konsumsi alkohol merupakan faktor yang sangat berkontribusi untuk terjadinya hipertensi pada suku asli Papua setelah faktor luar yaitu stres psikososial. Hal ini berarti bahwa apabila dalam keadaan stres dan sering mengonsumsi alkohol berlebihan dapat memicu terjadinya hipertensi pada suku asli Papua.

Alkohol dalam darah merangsang pelepasan epinefrin (adrenalin) dan hormon-hormon lain yang membuat pembuluh darah menyempit atau menyebabkan penumpukan lebih banyak Na dan air (27). Konsumsi alkohol harus dihindari karena konsumsi alkohol di atas 30-45 g/hari dapat meningkatkan tekanan darah. 
Meskipun awalnya efek alkohol bersifat reversible, tetapi apabila kebiasaan minum ini berlanjut secara terus menerus maka dapat terjadi gangguan regulasi tekanan darah sehingga kasus hipertensi banyak ditemukan pada peminum alkohol berat (30).

Penelitian pada pekerja di Australia menemukan bahwa rerata konsumsi alkohol setiap minggu berhubungan dengan tekanan darah sistolik tetapi tidak untuk tekanan darah diastolik. Tekanan darah sistolik akan meningkat seiring dengan meningkatnya konsumsi alkohol. Mereka yang mengkonsumsi alkohol secara berlebih memiliki prevalensi hipertensi 4 kali dibandingkan yang tidak minum alkohol. Efek dari alkohol terhadap tekanan darah sistolik berhubungan dengan usia, obesitas, merokok, dan aktivitas fisik (31).

\section{SIMPULAN DAN SARAN}

Hipertensi stage 2 cenderung terjadi pada suku non-Papua dibandingkan suku asli Papua. Asupan lemak, asupan K, dan konsumsi alkohol merupakan faktor risiko terjadinya hipertensi pada suku asli Papua sedangkan asupan lemak dan asupan $\mathrm{Na}$ merupakan faktor risiko terjadinya hipertensi pada suku non-Papua. Hasil analisis multivariat menunjukkan stres psikososial $(\mathrm{OR}=5,20)$ merupakan faktor yang paling berkontribusi untuk terjadinya hipertensi pada suku asli Papua, diikuti konsumsi alkohol, riwayat hipertensi, dan asupan K. Semantara itu, asupan lemak $(\mathrm{OR}=3,30)$ merupakan faktor yang paling berkontribusi untuk terjadinya hipertensi pada suku non-Papua, diikuti asupan $\mathrm{Na}$ berlebih dan obesitas.

Bagi suku non-Papua yang lebih cenderung terkena hipertensi stage 2 dan lebih berisiko terkena komplikasi akibat hipertensi, maka disarankan untuk bisa mengubah gaya hidup terutama dari faktor diet/makanan. Lebih teratur dalam memeriksakan tekanan darah ke pusat pelayanan kesehatan terdekat dan mengonsumsi obat antihipertensi yang diberikan. Selain itu, suku non-Papua harus mengurangi atau membatasi konsumsi makanan yang tinggi lemak dan $\mathrm{Na}$ termasuk memperhatikan cara pengolahan makanan dengan baik dan tepat. Mengurangi pemakaian bumbu penyedap, makanan yang diawetkan serta mengurangi pemakaian garam bagi yang mempunyai penyakit hipertensi. Faktor luar yang harus diperhatikan yaitu obesitas yang juga berkontribusi terhadap terjadinya hipertensi. Bagi pemerintah setempat, tokoh masyarakat, Ahli Gizi maupun tenaga kesehatan harus bekerjasama melakukan sosialisasi mengenai hipertensi dan cara pencegahan sejak dini.

Bagi suku asli Papua, harus mengurangi atau membatasi konsumsi makanan yang tinggi lemak dan meningkatkan konsumsi makanan tinggi $\mathrm{K}$ dengan cara menyertakan sayur dan buah setiap waktu makan. Pada suku asli Papua yang berisiko terkena hipertensi melalui konsumsi alkohol, maka disarankan untuk berhenti atau mengurangi konsumsi alkohol. Suku asli Papua yang memiliki riwayat keluarga hipertensi dan mengalami stres psikososial harus lebih serius memperhatikan kebiasaan konsumsi alkohol karena dapat memicu terjadinya hipertensi yang lebih akut dan berbahaya. Perlunya kerjasama dengan berbagai elemen masyarakat mengingat akibat yang bisa terjadi baik dari segi kesehatan maupun hukum. Komplikasi dan pengaruh jangka panjang harus diketahui oleh masyarakat bila terlalu banyak dan sering konsumsi alkohol.

\section{RUJUKAN}

1. Kearney PM, Perry IJ. Regional differences in blood pressure in developed countries. In: Lip GYH, Hall JE. Comprehensive hypertension. USA: Mosby Elsevier; 2007.

2. Darmojo BR. Bunga rampai karangan ilmiah Prof. Dr. R. Boedhi-Darmojo buku II: kardiovaskuler. Semarang: Bagian/UPF Ilmu Penyakit Dalam Fakultas Kedokteran Universitas Diponegoro/RS. Dr.Kariadi; 1996.

3. Depkes RI. Laporan Riskesdas Provinsi Papua 2008. Jakarta: Badan Penelitian dan Pengembangan Kesehatan; 2008.

4. Sigarlaki HJO. Karakteristik dan faktor berhubungan dengan hipertensi di Desa Bocor Kecamatan Bulus Pesantren Kabupaten Kebumen Jawa Tengah Tahun 2006. Makara Kesehatan 2006;4(2):78-88.

5. Carretero OA, Oparil S. Essensial hypertension: part I: definition and etiology. Circulation 2000;101:329-35.

6. Sugandi Y. Rekomendasi kebijakan mengenai Papua. Jakarta: Friedrich Ebert Stiffung (FEB) Indonesia; 2008.

7. Suhardjo. Sosio budaya gizi. Bogor: Departemen Pendidikan dan Kebudayaan Direktorat Jenderal Pendidikan Tinggi Pusat antar Universitas Pangan dan Gizi Institut Pertanian Bogor; 1989. 
8. Badan Pusat Statistik (BPS) Provinsi Papua. Neraca bahan makanan Provinsi Papua 2006/2007. Papua: BPS; 2006.

9. Kaplan NM. Hypertensive and atherosclerotic cardiovaskuler disease. In: Braunwald E, Zipes DP, Libby P. Heart disease: a text book of cardiovascular medicine, $6^{\text {th }}$ ed. USA: WB Saunders Company; 2001.

10. Dhianningtyas Y, Hendrati LY. Risiko obesitas, kebiasaan merokok, dan konsumsi garam terhadap kejadian hipertensi pada usia produktif. The Indonesian Journal of Public Health 2006;2(3):105-9.

11. Proboprastowo SM, Dwiriani CM. Angka kecukupan air dan elektrolit. Dalam: WNPG VIII. Ketahanan pangan dan gizi di era otonomi daerah dan globalisasi. Jakarta: Depkes, Badan POM, Bappena, Deptan, Ristek; 2004.

12. Stranges S, Wu T, Dorn JM, Freudenheim JL, Muti P, Farinaro E, Russell M, Nochajski TH, Trevisan M. Relationship of alcohol drinking pattern to risk of hypertension : a population - based study. Hypertension 2004;44(6):813-9.

13. Soewadi H. Simtomatologi dalam psikiatri. Yogyakarta: Medika Fakultas Kedokteran UGM; 1999.

14. Santoso M, Lyta, Pina. Gambaran pola komplikasi penderita hipertensi yang dirawat di RSUD Koja 20002004. Cermin Dunia Kedokteran 2006;150:47-9.

15. Mizwar. Faktor-faktor risiko terjadinya hipertensi esensial di Kabupaten Klaten [Tesis]. Yogyakarta: Universitas Gadjah Mada; 2004.

16. Mendez-chacon E, Santamaria-Ulloa C, Rosero-Bixby L. Factors associated with hypertension prevalence, unawareness and treatment among Costa Rican elderly. BMC Public Health 2008;8:275.

17. Kaplan NM, Flynn JT. Kaplan's clinical hypertension, 9th ed. USA: Lippincott Williams \& Wilkins; 2006.

18. He J, Muntner P, Chen J, Roccella EJ, Streiffer RH, Whelton PK. Factors associated with hypertension control in the general population of the United States. Arch Intern Med 2002;162(9):1051-8.

19. Lindeberg A, Berntrop E, Ehle-Nilson P, Terent A, Vessby B. Age relations of cardiovaskuler risk factors in a traditional Melanesian society: the Kitava Study. Am J clin Nutr 1997;66(4):845-52.

20. van Rossum CT1, van de Mheen H, Witteman JC, Hofman A, Mackenbach JP, Grobbee DE. Prevalence, treatmen, and control of hypertension by sociodemographic factors among the Dutch elderly. Hypertension 2000;35(3):81421.

21. Das SK, Sanyal K, Basu A. Study of urban community survey in india : growing trend of high prevalence of hypertension in a developing country. Int J Med Sci 2005;2(2):70-8.

22. Gillum RF. Pathophysiology of hypertension in blacks and whites: a review of the basis of racial bood pressure differences. Hypertension 1979;1(5):468-75.

23. Flack JM, Staffileno BA, Yunis C. Ethnicity and socioeconomic status in hypertension. In: Izzo JL, Black HR. Hypertension primer, the essentials of high blood pressure, $2^{\text {nd }}$ ed. USA: Council on High Blood Pressure research, American Heart Association; 1999.

24. Nugraheni SA, Fatimah S, Wayan IS. Pengaruh pola konsumsi dan status gizi terhadap tekanan darah. Berita Kedokteran Masyarakat 2001;XVII (4):189-96.

25. Riyadi A, Wiyono P, Budiningsari RD. Asupan gizi dan status gizi sebagai faktor risiko hipertensi esensial pada lansia di Puskesmas Curup dan Perumnas Kabupaten Rejang Lebong Provinsi Bengkulu. Jurnal Gizi Klinik Indonesia 2007;4(1):43-51.

26. Appel LJ, Espeland MA, Easter L, Wilson AC, Folmar S, Lacy CR. Effects of reduced sodium intake on hypertension control in older individuals: results from the Trial of Nonpharmacologic Interventions in the Elderly (TONE). Arch Intern Med 2001;161(5):685-93.

27. Sheps SG. Mayo clinic hipertensi mengatasi tekanan darah tinggi. (Alih bahasa). Jakarta: PT.Intisari Mediatama; 2005.

28. Almatsier S. Prinsip dasar ilmu gizi. Jakarta: PT Gramedia Pustaka Utama; 2004.

29. Susalit E, Kapojos EJ, Lubis HR. Hipertensi primer. Dalam: Suyono HS. Buku ajar ilmu penyakit dalam, edisi III. Jakarta: Balai Penerbit FKUI; 2001.

30. Rahardja EM. Faktor gizi dalam regulasi tekanan darah. Ebers Papyrus 2004;10(3):166-71.

31. Arkwright PD, Beilin LJ, Rouse I, Armstrong BK, Vandongen R. Effects of alcohol use and other aspects of lifestyle on blood pressure levels and prevalence of hypertension in a working population. Circulation 1982;66(1):60-6. 